\title{
Oriental Hornet (Vespa orientalis) Larval Extracts Induce Antiproliferative, Antioxidant, Anti-Inflammatory, and Anti-Migratory Effects on MCF7 Cells
}

\author{
Amina M. G. Zedan ${ }^{1}$ (D), Mohamed I. Sakran ${ }^{2,3}$, Omar Bahattab ${ }^{4}$, Yousef M. Hawsawi ${ }^{5,6} \mathbb{D}_{\text {, Osama Al-Amer }}{ }^{7,8}$, \\ Atif A. A. Oyouni ${ }^{8,9}$, Samah K. Nasr Eldeen ${ }^{10}\left(\mathbb{D}\right.$ and Mohammed A. El-Magd ${ }^{11, *}$
}

1 Biological and Environmental Sciences Department, Home Economic Faculty, Al Azhar University, Tanta 31732, Egypt; AminaZedan1948.el@Azhar.edu.eg

2 Biochemistry Department, Faculty of Science, University of Tabuk, Tabuk 47512, Saudi Arabia; msakran@ut.edu.sa

3 Biochemistry Division, Chemistry Department, Faculty of Science, Tanta University, Tanta 31512, Egypt

4 Biology Department, Faculty of Science, University of Tabuk, Tabuk 47512, Saudi Arabia; Obahattab@ut.edu.sa

5 Research Center, King Faisal Specialist Hospital and Research Center, MBC J04, Jeddah 21499, Saudi Arabia; hyousef@kfshrc.edu.sa

6 College of Medicine, Al-Faisal University, Riyadh 11533, Saudi Arabia

7 Department of Medical Laboratory Technology, Faculty of Applied Medical Sciences, University of Tabuk, Tabuk 47512, Saudi Arabia; oalamer@ut.edu.sa

check for updates

Citation: Zedan, A.M.G.; Sakran, M.I.; Bahattab, O.; Hawsawi, Y.M.; Al-Amer, O.; Oyouni, A.A.A.; Nasr Eldeen, S.K.; El-Magd, M.A. Oriental Hornet (Vespa orientalis) Larval Extracts Induce Antiproliferative, Antioxidant, Anti-Inflammatory, and Anti-Migratory Effects on MCF7 Cells. Molecules 2021, 26, 3303. https:// doi.org/10.3390/molecules26113303

Academic Editor: Luisa Tesoriere

Received: 24 April 2021

Accepted: 28 May 2021

Published: 31 May 2021

Publisher's Note: MDPI stays neutral with regard to jurisdictional claims in published maps and institutional affiliations.

Copyright: (c) 2021 by the authors. Licensee MDPI, Basel, Switzerland. This article is an open access article distributed under the terms and conditions of the Creative Commons Attribution (CC BY) license (https:// creativecommons.org/licenses/by/ $4.0 /)$.
8 Genome and Biotechnology Unit, Faculty of Sciences, University of Tabuk, Tabuk 47512, Saudi Arabia; a.oyouni@ut.edu.sa

9 Department of Biology, Faculty of Sciences, University of Tabuk, Tabuk 47512, Saudi Arabia

10 Central Laboratories, Egyptian Ministry of Health, Tanta 31512, Egypt; sciencesamah@gmail.com

11 Department of Anatomy, Faculty of Veterinary Medicine, Kafrelsheikh University, Kafrelsheikh 33516, Egypt

* Correspondence: mohamed.abouelmagd@vet.kfs.edu.eg

Abstract: The use of insects as a feasible and useful natural product resource is a novel and promising option in alternative medicine. Several components from insects and their larvae have been found to inhibit molecular pathways in different stages of cancer. This study aimed to analyze the effect of aqueous and alcoholic extracts of Vespa orientalis larvae on breast cancer MCF7 cells and investigate the underlying mechanisms. Our results showed that individual treatment with 5\% aqueous or alcoholic larval extract inhibited MCF7 proliferation but had no cytotoxic effect on normal Vero cells. The anticancer effect was mediated through (1) induction of apoptosis, as indicated by increased expression of apoptotic genes (Bax, caspase3, and p53) and decreased expression of the anti-apoptotic gene $B c l 2$; (2) suppression of intracellular reactive oxygen species; (3) elevation of antioxidant enzymes (CAT, SOD, and GPx) and upregulation of the antioxidant regulator Nrf2 and its downstream target $\mathrm{HO}-1$; (4) inhibition of migration as revealed by in vitro wound healing assay and downregulation of the migration-related gene $M M P 9$ and upregulation of the anti-migratory gene TIMP1; and (5) downregulation of inflammation-related genes (NFKB and IL8). The aqueous extract exhibited the best anticancer effect with higher antioxidant activities but lower anti-inflammatory properties than the alcoholic extract. HPLC analysis revealed the presence of several flavonoids and phenolic compounds with highest concentrations for resveratrol and naringenin in aqueous extract and rosmarinic acid in alcoholic extract. This is the first report to explain the intracellular pathway by which flavonoids and phenolic compounds-rich extracts of Vespa orientalis larvae could induce MCF7 cell viability loss through the initiation of apoptosis, activation of antioxidants, and inhibition of migration and inflammation. Therefore, these extracts could be used as adjuvants for anticancer drugs and as antioxidant and anti-inflammatory agents.

Keywords: Vespa orientalis; MCF7; apoptosis; antioxidant; anti-migration; anti-inflammatory 


\section{Introduction}

Despite remarkable advances in chemotherapy, the numerous side effects and nonselective targeting of most of the currently used anticancer drugs restrict their therapeutic potential $[1,2]$. Thus, discovering novel anticancer agents with superior inhibitory effect and selective targeting to cancer cells is becoming an urgent need [3-5]. In recent years, targeted therapy has been searching for natural and safe medicines to avoid the side effects of anticancer drugs [6,7]. Extracts prepared from natural products and medicinal plants have notable anti-inflammatory, antioxidant and anticancer potential [3-7]. Similarly, many bioactive ingredients extracted from insects have demonstrated anticancer effects [8-11]. Insects and their larvae could be considered as a good source for many bioactive compounds; however, their role has not been fully investigated [12]. Previous studies have reported that some insect larvae, such as housefly larvae, possess anticancer, antioxidant, and antimicrobial properties [11,13-16]. Additionally, aqueous extracts and hydrolysates of some insects such as house cricket, grasshopper, and silk moth contain some beneficial bioactive peptides that have anti-inflammatory and antioxidant activities [17,18]. In addition to these beneficial medicinal effects, insects are part of the common diet of at least two billion people in the world, as they contain high amounts of proteins and micronutrients [19]. Consumption of antioxidant-rich nutrients helps in preventing oxidative stress-induced diseases and cancer [5,20-23].

Oriental hornets (Vespa orientalis) are insects that belong to the family Vespidae, which are distributed in the Middle East, Southwest Asia, Southern Europe, and Northeast Africa, and live in colonies [24]. The fertilized queens hibernate in the winter $[25,26]$, lay their eggs during the fall [27], and the population of the colony peaks in the late summer and initial fall [28]. These insects attack bee colonies to get nectar and protein, causing notable loss to honey bee production $[29,30]$. Although their stings are highly painful to humans and can cause allergy, they are used for the treatment of cold and gastritis in some Indian tribes [26]. These tribes also consume various Vespa sp. due to their high protein content [31]. Moreover, the aqueous extract of lesser banded hornet ( $V$. affinis) has been shown to exert antioxidant effects through activation of the antioxidant enzymes GST and CAT [32]. Venom extracted from $V$. orientalis showed a potent antimicrobial effect against a large variety of bacteria [33-35] and an anticancer effect [36-38]. One of the major drawbacks of using insect venoms as an anticancer agent is their cytotoxic and neurotoxic effects on normal cells [39,40]. Using insect larva and pupa could be a useful alternative. However, to date, there have been no reports investigating the antioxidant and anticancer effects of $V$. orientalis larval extracts.

Therefore, this study aimed to assess the anticancer effect of aqueous and alcoholic extracts of $V$. orientalis larvae against MCF7 cells and to study the underlying mechanisms through investigating apoptotic pathway, antioxidant status, migration, and inflammation.

\section{Material and Methods}

\subsection{Preparation of $V$. orientalis Larval Extracts}

Nests of V. orientalis were collected in the fall of 2019 from different localities in the cities of Tanta and Kafrelsheikh, Egypt. The insects and nests were kept under controlled conditions with respect to temperature, relative humidity, and photoperiods in the Honey Bee Laboratory at Plant Protection Department, Faculty of Agriculture, Kafrelsheikh University. A standard rearing method was used to obtain the larvae required for the bioassay. The 3rd and 4th larvae instars were extracted using $5 \%$ water or ethyl alcohol as previously described [32,41]. In brief, the collected larvae were first washed in distilled water, and a mixture of $5 \mathrm{~g}$ larvae and $95 \mathrm{~mL}$ distilled water or pure ethyl alcohol was centrifuged $\left(8000 \mathrm{rpm} / 20 \mathrm{~min} / 4^{\circ} \mathrm{C}\right.$ ) to eliminate undesirable debris. The supernatant was obtained and considered as $5 \%$ aqueous and alcoholic extracts and kept in the freezer until further use. 


\subsection{HPLC Analysis of Flavonoids and Phenolic Compounds}

HPLC was used to analyze flavonoids and phenolic compounds in both aqueous and alcoholic extracts, as previously described [42]. The HPLC (Agilent1260 infinity HPLC Series, Agilent Technologies, Santa Clara, CA, USA) was equipped with a Quaternary pump and Kinetex $5 \mu \mathrm{m}$ EVO C18 $(100 \mathrm{~mm} \times 4.6 \mathrm{~mm})$ column (Phenomenex, Torrance, CA, USA) operated at $30^{\circ} \mathrm{C}$. The separation was achieved using a ternary linear elution gradient with HPLC grade water $0.2 \% \mathrm{H} 3 \mathrm{P} 04(v / v)$, methanol, and acetonitrile. The injected volume was $20 \mu \mathrm{L}$ and the VWD detector was set at $284 \mathrm{~nm}$.

\subsection{DPPH Radical Scavenging Assay}

A DPPH (2,2-diphenyl-1-picryl-hydrazil) radical scavenging assay was performed as previously described [43]. A methanolic solution of DPPH reagent $(1 \mathrm{~mL}, 0.004 \%)$ was added to each larval extract $(100 \mu \mathrm{L})$ dissolved in DMSO at different concentrations $(20,40,80,160$, and $320 \mu \mathrm{g} / \mathrm{mL})$. Following $1 \mathrm{~h}$ incubation in the dark, a yellow color developed, and the absorbance was recorded at $515 \mathrm{~nm}$. Ascorbic acid was used as a positive control. The $\mathrm{IC}_{50}$ value was calculated using GraphPad prism. The experiment was repeated three times. The DPPH scavenging activity was calculated from this equation: $\mathrm{DPPH}$ scavenging $(\%)=(\mathrm{A} 0-\mathrm{A} 1) / \mathrm{A} 0 \times 100$, where $\mathrm{A} 0$ is the control absorbance and $\mathrm{A} 1$ is the sample absorbance.

\subsection{MTT Cytotoxicity Assay}

Human breast adenocarcinoma MCF7 cells and normal African green monkey kidney Vero cells were obtained from VACSERA, Cairo. MTT assay was performed as previously described [44]. Cells were seeded at a concentration of $1 \times 10^{4}$ cells per well. DMEM medium, 10\% FBS, $1 \%$ penicillin/streptomycin, and 2\% L-glutamine (all supplemented from Gibco, Waltham, MA, USA) were added to each well, and cells were incubated at $37^{\circ} \mathrm{C}$, in a humidified atmosphere of $95 \%$ air and $5 \% \mathrm{CO}_{2}$ for $24 \mathrm{~h}$ until $80-90 \%$ confluence. Serial dilutions $(0,12.5,25,50,100$, and $200 \mu \mathrm{g} / \mathrm{mL})$ of each $V$. orientalis larval extract were applied to cells. Following incubation for 1 day, $5 \mathrm{mg} / \mathrm{mL}$ of 3-(4,5-Dimethylthiazol-2-yl)2,5-diphenyltetr-azolium bromide (MTT, Invitrogen, Waltham, MA, USA) was added, and cells were incubated for $4 \mathrm{~h}$; then, the medium was removed and substituted with $100 \mu \mathrm{L}$ Dimethyl sulfoxide (DMSO, Sigma Aldrich, St. Louis, MO, USA). Finally, the absorbance was measured at $570 \mathrm{~nm}$.

\subsection{Experimental Design}

The cells were allocated into three groups. The untreated MCF7 cells were considered control cells (Cnt), while in the other two groups, cells were treated with aqueous or alcoholic larval extracts with doses equal to their $\mathrm{IC}_{50}$. Treatments were applied in triplicate at 70-80\% confluence. Cells were incubated in a $\mathrm{CO}_{2}$ incubator for $24 \mathrm{~h}$ at $37^{\circ} \mathrm{C}$ and $95 \%$ humidity.

\subsection{Estimation of Intracellular Reactive Oxygen Species}

Intracellular reactive oxygen species (ROS) were determined using a fluorescent probe, $2^{\prime}, 7^{\prime}$-dichlorofluorescein diacetate (DCFDA), as previously described [45]. MCF7 cells were treated with aqueous and alcoholic larval extracts with doses equal to their $\mathrm{IC}_{50}$ for $2 \mathrm{~h}$ followed by $25 \mu \mathrm{M} \mathrm{H}_{2} \mathrm{O}_{2}$ for $2 \mathrm{~h}$. After PBS washing, DCFDA $(5 \mu \mathrm{M})$ was added, and the cells were incubated $\left(37^{\circ} \mathrm{C} / 30 \mathrm{~min}\right)$ in the dark. Following washing in PBS, the fluorescence intensity of DCFDA was measured in a fluorescence microplate reader. The intracellular ROS levels were calculated as a \% of the control.

\subsection{Detection of Antioxidant Enzymes Activities}

The activities of superoxide dismutase activity (SOD), catalase (CAT), glutathione peroxidase (GPx) in MCF7 cells were assayed by colorimetric methods using commercially available kits and following the manufacturer's protocol (Biodiagnostics, Cairo, Egypt). The antioxidant activities were presented as percentages of the control. 


\subsection{In Vitro Scratch (Wound Healing) Assay}

MCF7 cells were grown at a concentration of $2.5 \times 10^{5}$ cells $/ \mathrm{mL}$ in 6-well plates in DMEM until 75\% confluence. A scratch was produced in the center of each well and fresh media containing each extract at a concentration equal to $\mathrm{IC}_{50}$ were added. Images were taken at two time intervals $(0 \mathrm{~h}$ and $24 \mathrm{~h})$, and MCF7 migration was calculated as previously reported [46].

\subsection{Gene Expression Analysis by $q P C R$}

RNA samples were extracted from all cells using a procedure detailed previously [6]. Nanodrop and 1\% gel electrophoresis were used to determine RNA concentration and integrity, respectively. Following reverse transcription using RevertAid H Minus Reverse Transcriptase, the expression of $B a x, B c l 2$, caspase 3, p53, NrF2, HO-1, MMP9, TIMP1, NFאB, and IL8 genes was determined using 2X SYBR Green Master Mix and specific primers (Table 1). All kits used in qPCR were purchased from Thermo Scientific, Waltham, MA, USA. The qPCR mixture $(25 \mu \mathrm{L})$ contained $2 \mu \mathrm{L}$ cDNA, $1 \mu \mathrm{L}$ from each primer and $12.5 \mu \mathrm{L}$ of Maxima SYBR Green Master Mix. The thermal cycling included $10 \mathrm{~min}$ at $95^{\circ} \mathrm{C}$ followed by 45 cycles of $\left(95^{\circ} \mathrm{C}\right.$ for $15 \mathrm{~s}, 60^{\circ} \mathrm{C}$ for $30 \mathrm{~s}$ and 72 for $30 \mathrm{~s}$ ). The relative expression of target genes was normalized with the housekeeping gene GAPDH and calculated using the $2^{-\Delta \Delta \mathrm{Ct}}$ method [47].

Table 1. Primer sequences used in qPCR.

\begin{tabular}{|c|c|c|}
\hline Gene & Forward Primer $\left(5^{\prime}-3^{\prime}\right)$ & Reverse Primer $\left(5^{\prime}-3^{\prime}\right)$ \\
\hline $\mathrm{Bax}$ & GGACGAACTGGACAGTAACATGG & GCAAAGTAGAAAAGGGCGACAAC \\
\hline $\mathrm{Bcl} 2$ & TTGATGGGATCGTTGCCTTATGC & CAGTCTACTTCCTCTGTGATGTTG \\
\hline Cas3 & GAAGCGAATCAATGGACTCTGG & GACCGAGATGTCATTCCAGTGC \\
\hline p53 & TAACAGTTCCTGCATGGGCGGC & AGGACAGGCACAAACACGCACC \\
\hline $\mathrm{NrF} 2$ & CAGCGACGGAAAGAGTATG & TGGGCAACCTGGGAGTAG \\
\hline $\mathrm{HO}-1$ & CGGGCCAGCAACAAAGTG & AGTGTAAGGACCCATCGGAGAA \\
\hline MMP9 & GCCACTACTGTGCCTTTGAGTC & CССTCAGAGAATCGCCAGTACT \\
\hline TIMP1 & GGGCTTCACCAAGACCTACA & TGCAGGGGATGGATAAACAG \\
\hline NFKB & ATGGCTTCTATGAGGCTGAG & GTTGTTGTTGGTCTGGATGC \\
\hline IL8 & ACTGAGAGTGATTGAGAGTGGAC & AACCCTCTGCACCCAGTTTTC \\
\hline GAPDH & GGTGAAGGTCGGAGTCAACG & TGAAGGGGTCATTGATGGCAAC \\
\hline
\end{tabular}

\subsection{Statistical Analysis}

All data were expressed as mean \pm standard error of the mean (SEM) of replicates from independent experiments. The difference between the groups was evaluated by oneway analysis of variance and Tukey's Honest Significant Difference test using GraphPad prism, 7.0 software. Values were considered statistically significant when $p<0.05$.

\section{Results}

\subsection{Larval Extract Had Numerous Flavonoids and Phenolic Compounds}

HPLC chromatograms for the $5 \%$ aqueous larval extract revealed the presence of numerous flavonoids (catechin, chlorogenic, rutin, quercetin, naringenin, myricetin) and phenolic compounds (vanillic acid, caffeic acid, syringic acid, ferulic acid, o-coumaric acid, resveratrol, and rosmarinic acid), as well as benzoic acid and p-hydroxybenzoic acid (a phenolic derivative of benzoic acid), p-coumaric acid, benzoic acid, and cinnamic acid. Resveratrol was the major phenolic compound $(1.580 \mathrm{mg} / \mathrm{kg}$ at $19.74 \mathrm{~min})$, while naringenin was the major flavonoid $(0.819 \mathrm{mg} / \mathrm{kg}$ at $22.56 \mathrm{~min})$ (Table 2, Figure $1 \mathrm{~A})$. 
Table 2. Flavonoids and phenolic compounds composition of 5\% aqueous and alcoholic larval extracts.

\begin{tabular}{|c|c|c|c|c|}
\hline \multirow{2}{*}{ Compounds } & \multicolumn{2}{|c|}{ Aqueous Larval Extract } & \multicolumn{2}{|c|}{ Alcoholic Larval Extract } \\
\hline & Retention Time (min) & Amount (mg/kg) & Retention Time (min) & Amount (mg/kg) \\
\hline Catechol & 5.40 & - & 5.40 & - \\
\hline p-Hydroxy benzoic acid & 7.68 & 0.019 & 7.70 & - \\
\hline Catechin & 8.92 & 0.011 & 8.88 & 0.873 \\
\hline Chlorogenic & 9.30 & - & 9.30 & - \\
\hline Vanillic acid & 9.88 & 0.114 & 9.70 & 0.679 \\
\hline Caffeic acid & 10.15 & 0.020 & 9.93 & 0.675 \\
\hline Syringic acid & 10.37 & 0.025 & 10.50 & - \\
\hline p-Coumaric acid & 13.45 & - & 13.45 & - \\
\hline Benzoic acid & 14.27 & 0.032 & 14.30 & - \\
\hline Ferulic acid & 15.42 & 0.004 & 15.69 & 0.337 \\
\hline Rutin & 16.79 & 0.375 & 16.70 & - \\
\hline Ellagic & 16.90 & - & 17.08 & 0.920 \\
\hline o-Coumaric acid & 17.43 & 0.029 & 17.40 & - \\
\hline Resveratrol & 19.74 & 1.580 & 19.80 & - \\
\hline Cinnamic acid & 20.20 & - & 20.20 & - \\
\hline Quercetin & 21.20 & 0.350 & 21.60 & - \\
\hline Rosemarinic & 21.81 & 0.679 & 21.83 & 34.031 \\
\hline Naringenin & 22.56 & 0.819 & 22.40 & - \\
\hline Myricetin & 23.58 & 0.396 & 23.48 & - \\
\hline Kampherol & 24.70 & - & 24.70 & - \\
\hline Total & & 4.452 & & 45.460 \\
\hline
\end{tabular}

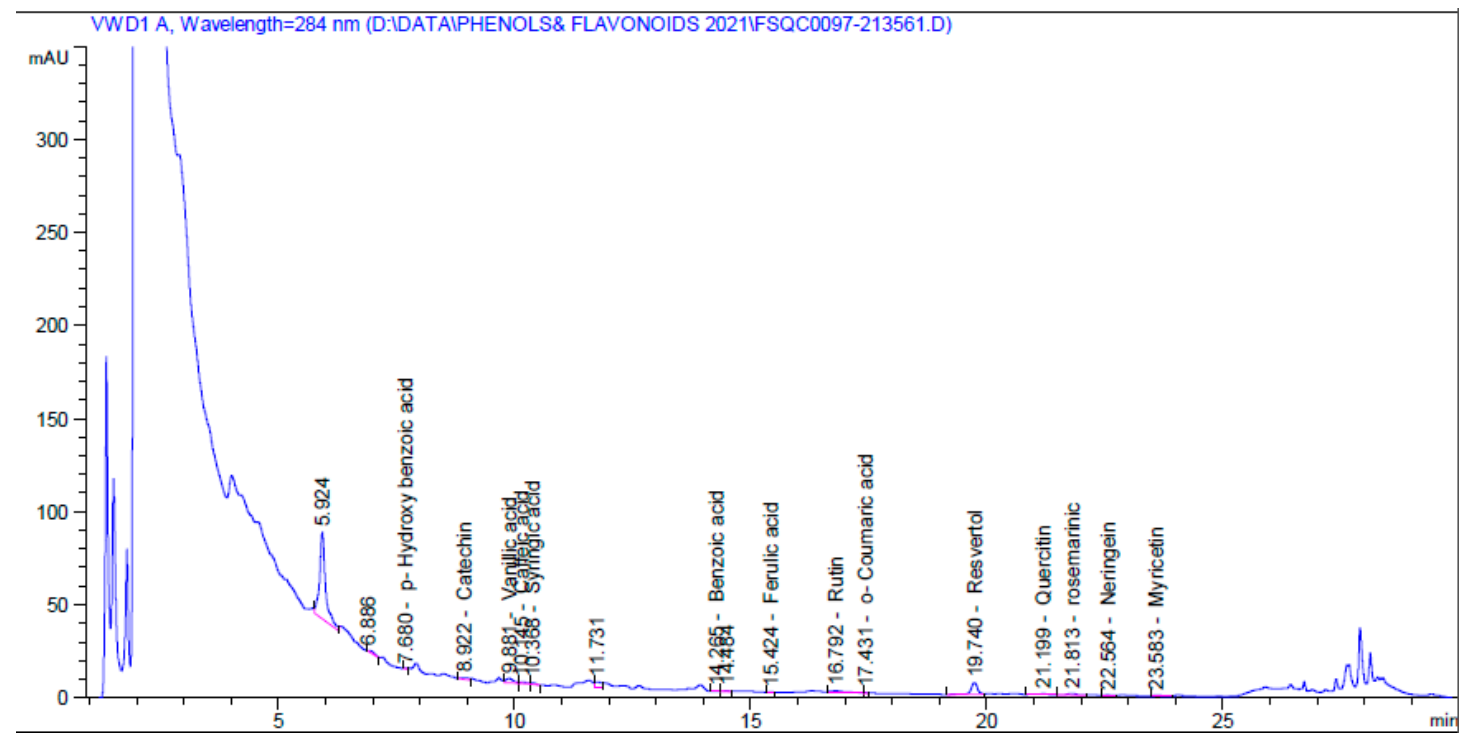

(A)

Figure 1. Cont. 


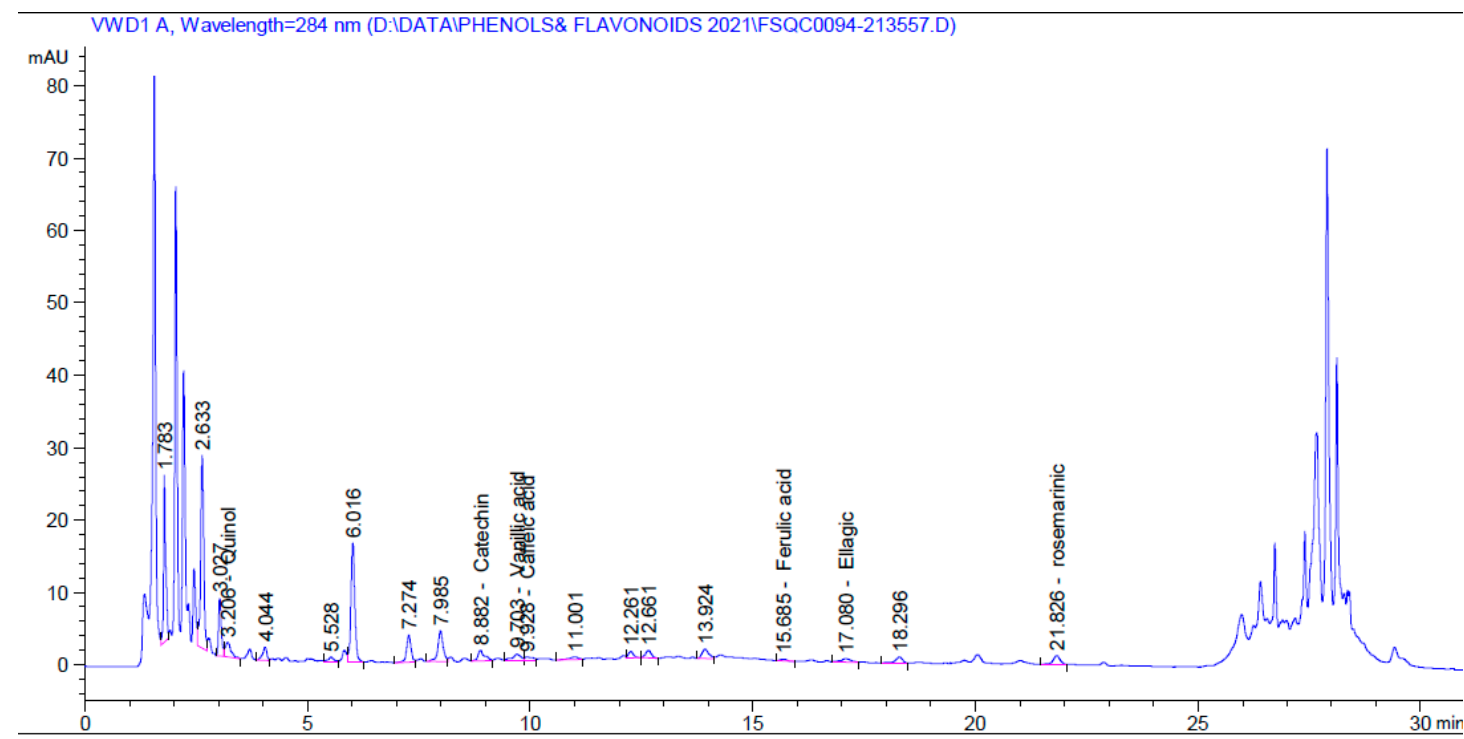

(B)

Figure 1. HPLC chromatograms of 5\% aqueous (A) and alcoholic (B) larval extracts.

On the other hand, the 5\% alcoholic larval extract contained only catechin flavonoid and fewer phenolic compounds (vanillic acid, caffeic acid, ferulic acid, ellagic acid, and rosmarinic acid). However, the total phenolic compounds and flavonoids $(45.460 \mathrm{mg} / \mathrm{kg})$ were higher than those of the $5 \%$ aqueous larval extract $(4.452 \mathrm{mg} / \mathrm{kg})$. The major phenolic compound obtained from the alcoholic larval extract was rosmarinic acid ( $34.031 \mathrm{mg} / \mathrm{kg}$ at $21.83 \mathrm{~min}$ ), which was responsible for this elevation (Table 2, Figure 1B). Looking at the HPLC chromatograms displayed in Figure 1, other unknown higher peaks can be observed that were not identified due to lack of available standards.

\subsection{Larval Extract Had Potent Antioxidant Activities}

The HPLC results indicated the presence of numerous flavonoids and phenolic compounds, which all had antioxidant properties. This prompted us to confirm the in vitro antioxidant activities of the two larval extracts using DPPH assay. As expected, $5 \%$ aqueous and alcoholic larval extracts had potent free radical scavenging activity, with $\mathrm{IC}_{50}$ values of $52.67 \pm 2.38$ and $123.50 \pm 4.62 \mu \mathrm{g} / \mathrm{mL}$, respectively, relative to the standard ascorbic acid $(45.33 \mu \mathrm{g} / \mathrm{mL}$ ) (Figure 2). This suggests that the $5 \%$ aqueous larval extract had better free radical scavenging activity than the $5 \%$ alcoholic larval extract.
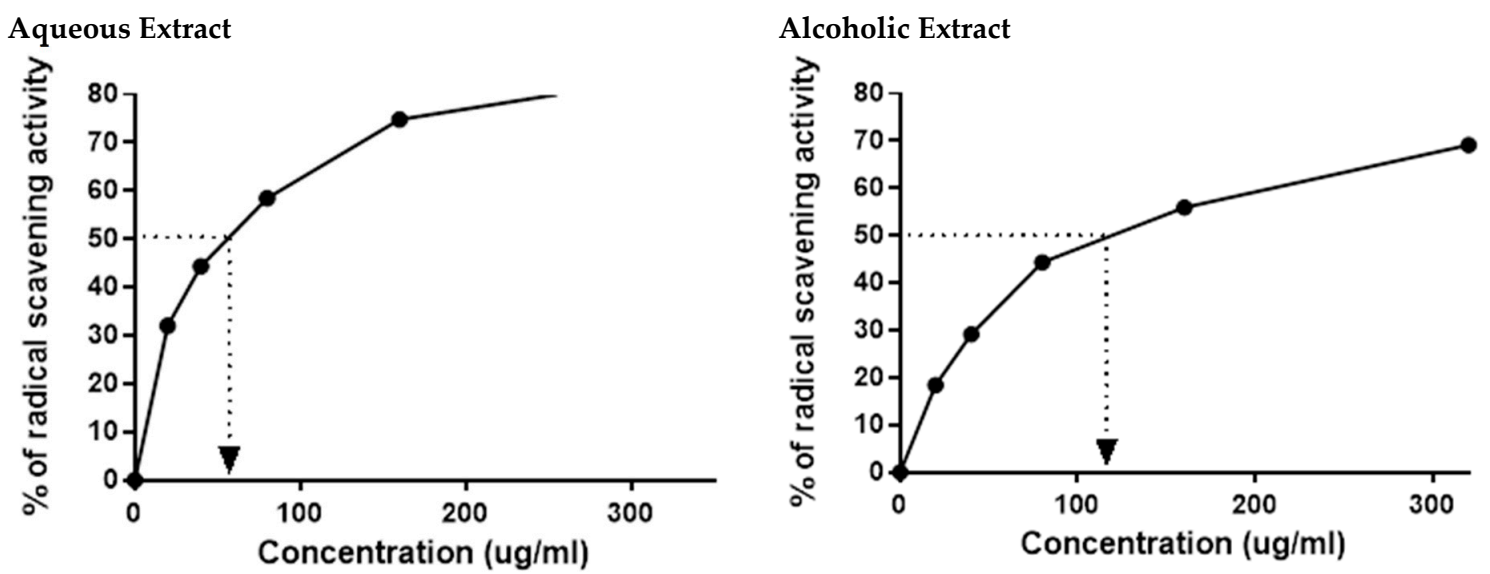

Figure 2. DPPH radical scavenging activity of $5 \%$ aqueous and alcoholic larval extracts shows their $\mathrm{IC}_{50}$ values $(52.67 \pm 2.38$ and $123.50 \pm 4.62 \mu \mathrm{g} / \mathrm{mL}$, respectively). Values are mean \pm SEM. Samples were run in triplicate in three independent experiments, $n=5$. 


\subsection{Larval Extracts Inhibited MCF7 Viability}

The results of MTT assay showed dose-dependent cytotoxic effects for $5 \%$ aqueous and alcoholic larval extracts on MCF7, with $\mathrm{IC}_{50}$ values of $32.89 \pm 1.84$ and $61.48 \pm 2.70 \mu \mathrm{g} / \mathrm{mL}$, respectively, as compared to control (untreated) cells (Figure 3). This suggests that the aqueous larval extract had a more potent anticancer effect than the alcoholic larval extract. However, the aqueous extract showed no cytotoxic effect on normal Vero cells up to a concentration of $100 \mu \mathrm{g} / \mathrm{mL}$, and only $1 \%$ cell viability inhibition was noticed at a concentration of $200 \mu \mathrm{g} / \mathrm{mL}$. The alcoholic extract also showed minimal inhibition of $0.50 \%$, $1.5 \%$ and $4.5 \%$ at concentrations of 50,100 , and $200 \mu \mathrm{g} / \mathrm{mL}$, respectively (Figure 3 ).

$5 \%$ aqueous extract
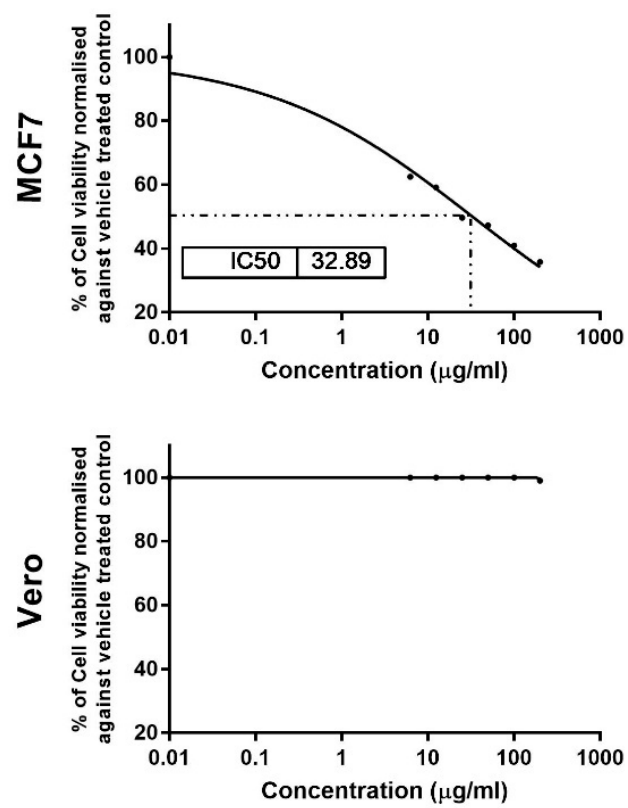

$5 \%$ alcoholic extract
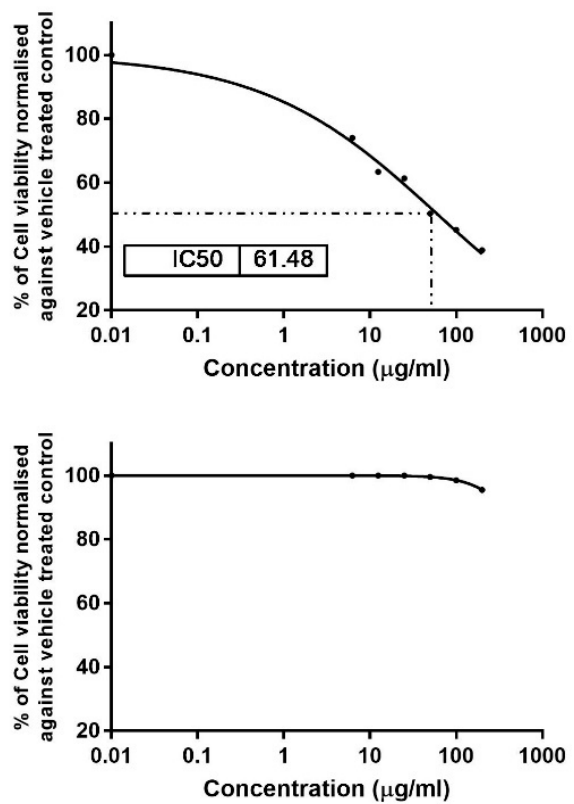

Figure 3. Cytotoxicity analysis of the 5\% larval extracts using the MTT assay. Dose-response curves show the effect of the two extracts on MCF7 and Vero viability and the obtained $\mathrm{IC}_{50}$ after $24 \mathrm{~h}$. Data were normalized to untreated control cells and expressed as the mean \% viability \pm SEM. Samples on MCF7 and Vero were run in triplicate in three independent experiments, $n=5$.

\subsection{Larval Extracts Modulated the Expression of Apoptosis-Related Genes}

The qPCR was applied to monitor the effect of treatments on the expression of the apoptotic genes (Bax, caspase3, and p53) and the anti-apoptotic gene (Bcl2). Treatment with each extract significantly upregulated the expression of the apoptotic genes and significantly downregulated the expression of $B c l 2$ compared to the control cells (Figure 4). The $5 \%$ aqueous extract showed higher expression of $B a x$ and caspase 3 and lower expression of $\mathrm{Bcl} 2$ than the $5 \%$ alcoholic extract. These results suggest that the cytotoxic effect of the two extracts on MCF7 cells could be triggered by apoptosis. On the other hand, no significant difference was observed in any of these apoptotic or anti-apoptotic genes among the three groups in Vero cells (Figure S1). These results imply that the two larval extracts would not induce apoptosis in normal Vero cells. 

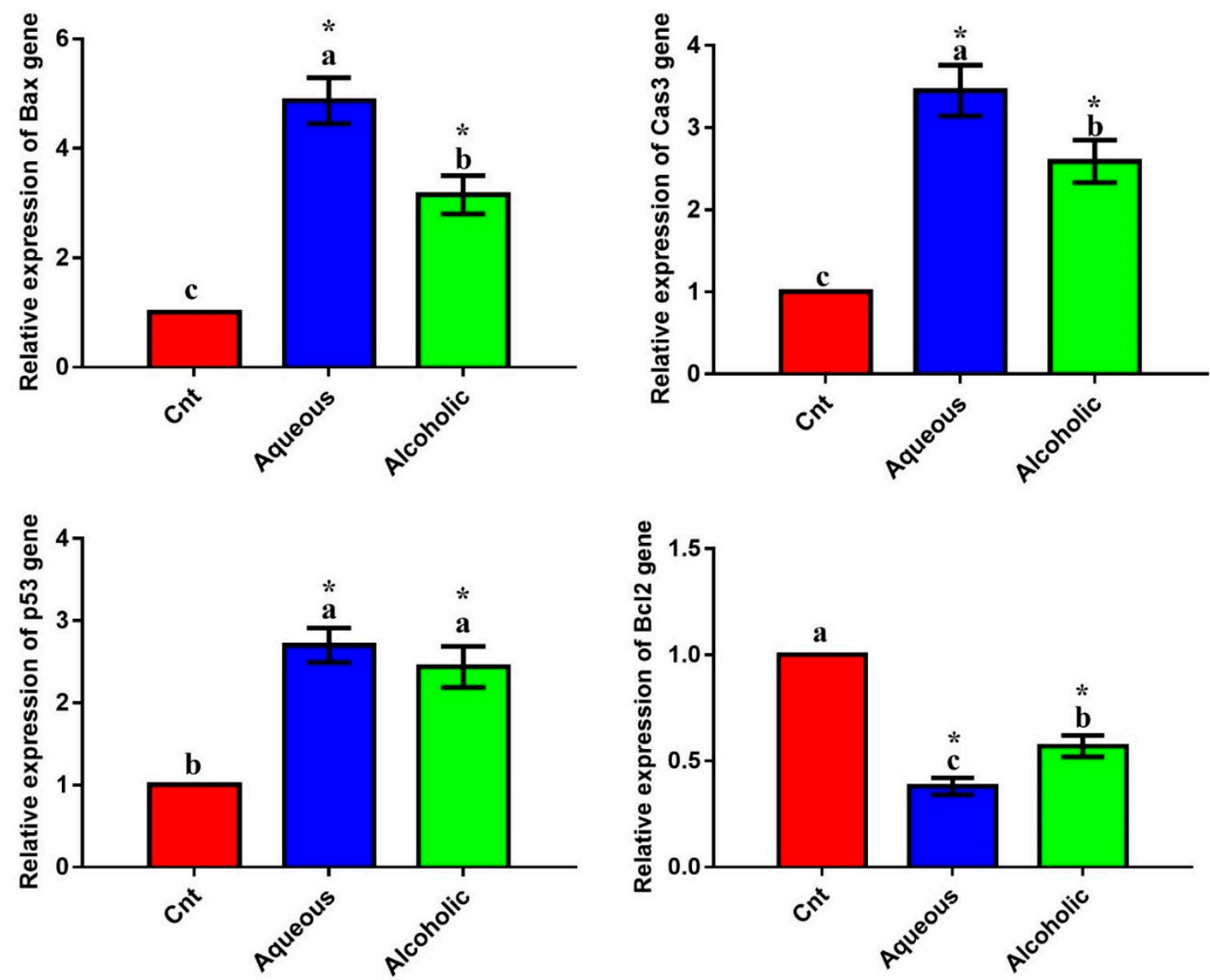

Figure 4. Expression of Bax, caspase3 (Cas3), p53, and Bcl2 genes in MCF7 cells following treatment with 5\% aqueous and alcoholic larval extracts as detected by qPCR. Data were normalized to the housekeeping gene (GAPDH) and are expressed as the mean fold change \pm SEM. Samples were run in triplicate in three independent experiments, $n=5$. Groups with different letters are significantly different at $p<0.05{ }^{*}$ indicates high significance with respect to control $(p<0.001)$.

\subsection{Larval Extracts Inhibited Intracellular ROS and Induced Antioxidant Status}

Given that $V$. orientalis larval extracts contained numerous flavonoids and phenolic compounds and had potent total antioxidant activities, we postulated that these extracts could trigger cancer cell death through decreasing oxidative stress and increasing antioxidant enzyme activities. To assess this hypothesis, we evaluated the effect of these extracts on the intracellular ROS and activities of antioxidant enzymes. Increased intracellular ROS is a notable indicator of cellular oxidative stress. As was expected, cells treated with each larval extract showed significantly lower intracellular ROS and significantly higher levels of CAT, SOD, and GPx than control cells (Figure 5). Again, the 5\% aqueous extract exhibited lower intracellular ROS and higher levels of CAT, SOD, and GPx than the 5\% alcoholic extract. 

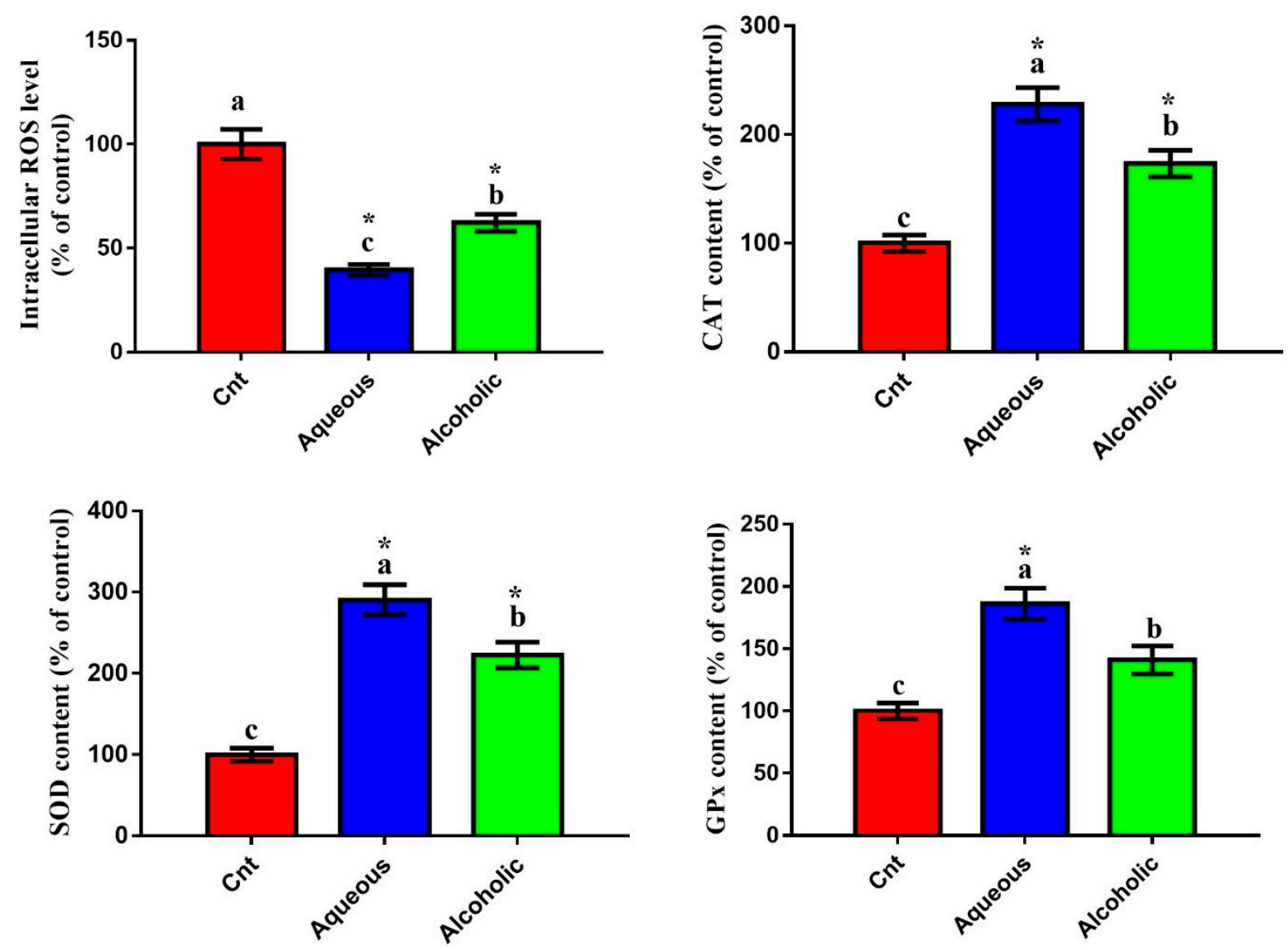

Figure 5. Effect of 5\% aqueous and alcoholic larval extracts on intracellular ROS and activities of antioxidant enzymes (CAT, SOD, and GPx) in MCF7 cells. Data are expressed as \% of the control \pm SEM. Samples were run in triplicate in three independent experiments, $n=5$. Groups with different letters are significantly different at $p<0.05$. ${ }^{*}$ indicates high significance with respect to the control $(p<0.01)$.

To confirm the antioxidant potential of the two extracts on a molecular basis, we studied their effect on the expression of the antioxidant-regulator $N r F 2$ and its downstream target $\mathrm{HO}-1$ using qPCR and found significant upregulation of the two genes in MCF7 cells treated with each extract, with higher expression in 5\% aqueous extract-treated cells than in control cells (Figure 6).

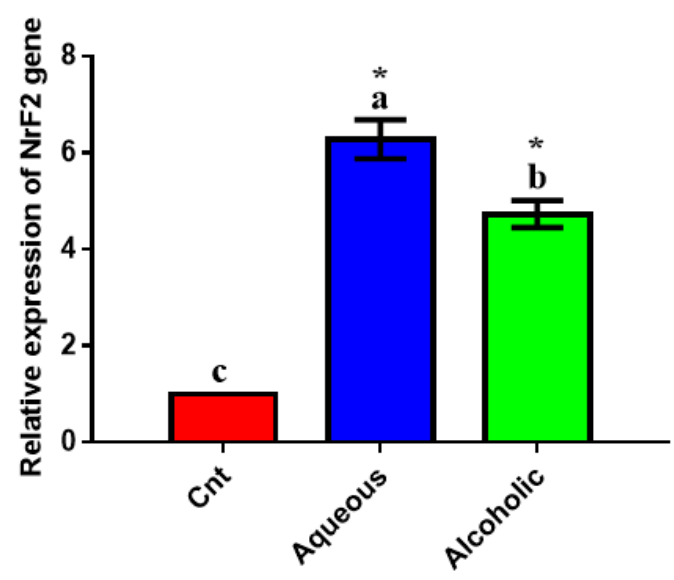

Figure 6. Cont. 


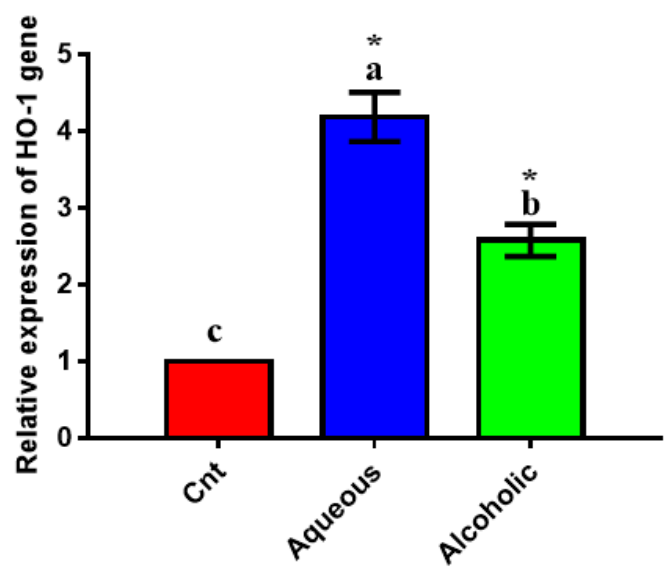

Figure 6. Expression of $\mathrm{NrF2}$ and $\mathrm{HO}-1$ genes in MCF7 cells following treatment with $5 \%$ aqueous and alcoholic larval extracts as detected by qPCR. Data were normalized to the housekeeping gene $(G A P D H)$ and are expressed as the mean fold change \pm SEM. Samples were run in triplicate in three independent experiments, $n=5$. Groups with different letters are significantly different at $p<0.05$. * indicates high significance with respect to control $(p<0.001)$.

\subsection{Larval Extracts Inhibited MCF7 Migration}

The effect of larval extracts on MCF7 migration was evaluated using a scratch (woundhealing) assay. Treatment with each larval extract significantly inhibited MCF7 migration compared to the control (Figure 7). The rates of MCF7 migration after treatment with aqueous and alcoholic extracts were $34.68 \pm 2.63 \%$ and $42.28 \pm 3.14 \%$, respectively, compared to the control cells $(60.38 \pm 4.12 \%)$. To verify this anti-migratory effect on a molecular level, qPCR was used to check changes in the relative expression of the migration-related MMP9 and the anti-migratory TIMP1 following treatment with each larval extract. The obtained results revealed significant downregulation of $M M P 9$ and upregulation of TIMP1 in cells treated with each extract relative to control cells (Figure 7). No significant change in MMP9 or TIMP1 was noticed between the two extracts.

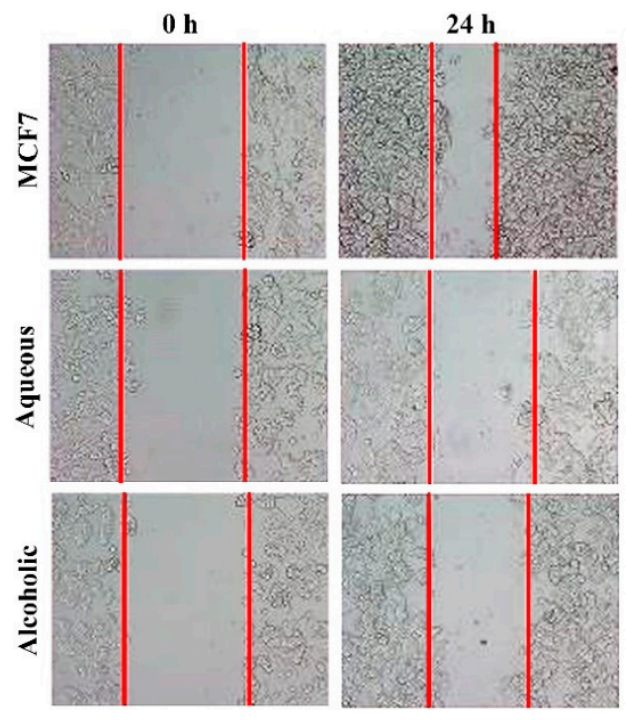

(A)

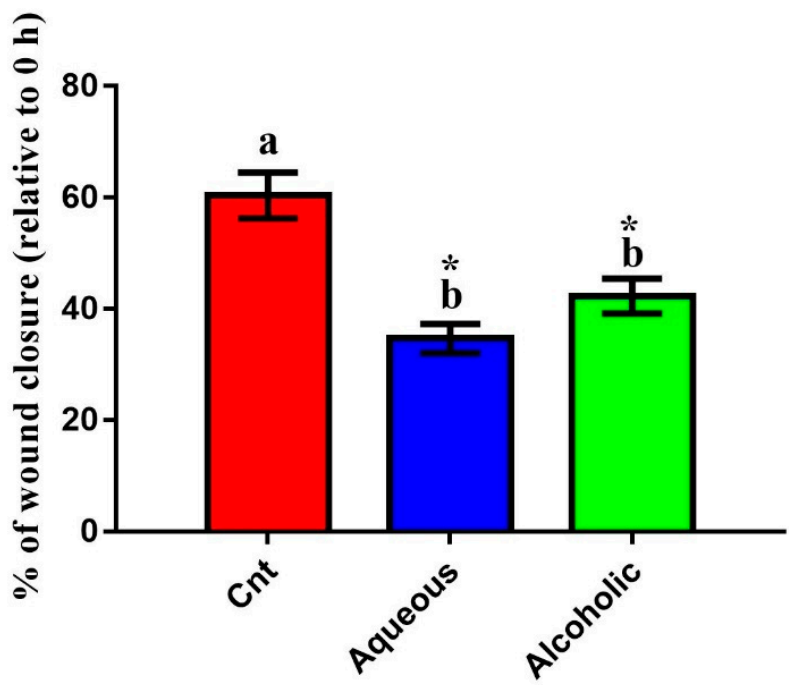

(B)

Figure 7. Cont. 

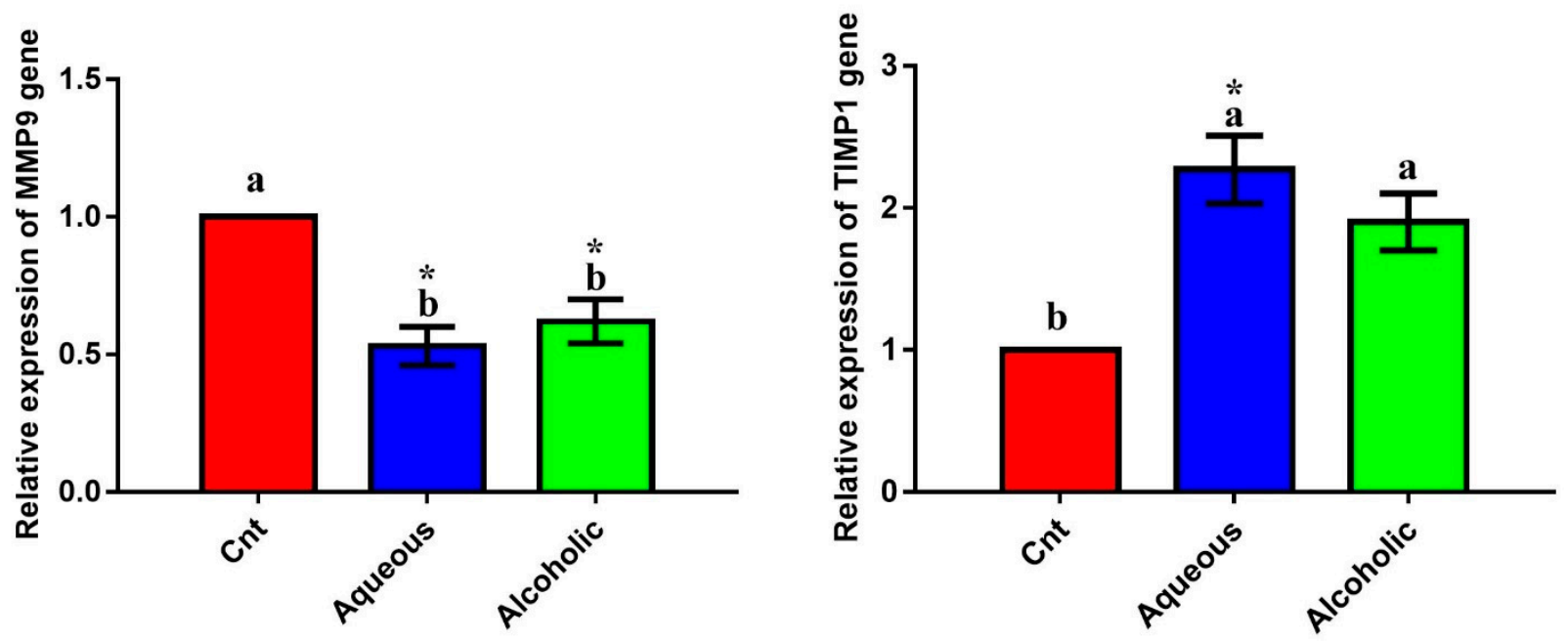

(C)

Figure 7. Anti-migratory effect of 5\% aqueous and alcoholic larval extracts on MCF7 cells. (A) Wound-healing assay. (B) Percentage of wound closure of MCF7 cells. (C) Expression of MMP9 and TIMP1 genes in MCF7 cells. Data are expressed as the mean \pm SEM. Samples were run in triplicate in three independent experiments, $n=5$. Groups with different letters are significantly different at $p<0.05 .{ }^{*}$ indicates high significance with respect to the control $(p<0.01)$.

\subsection{Larval Extracts Reduced the Expression of Inflammation-Related Genes}

The inflammatory genes $N F \kappa B$ and IL8 exhibited a significant downregulation after the addition of each extract compared to the control cells (Figure 8). The most downregulated effect was encountered in cells treated with the $5 \%$ alcoholic extract. These findings indicate that these extracts have an anti-inflammatory effect against MCF7 cells, with the best effect being for the $5 \%$ alcoholic extract.
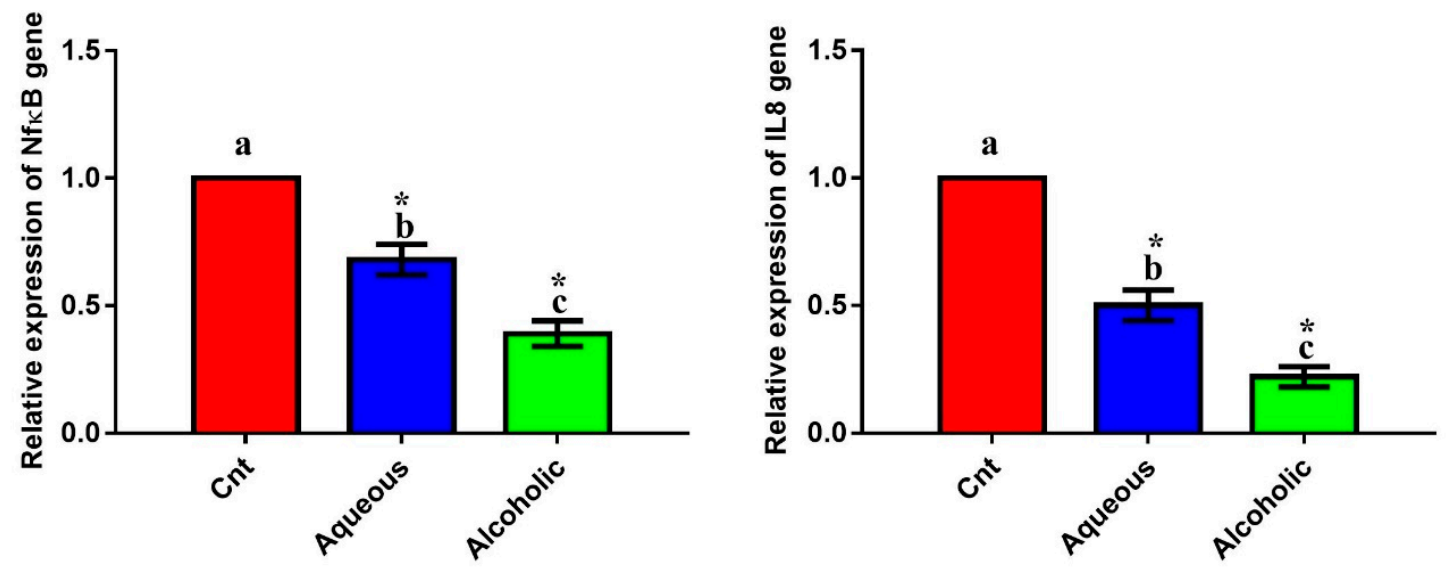

Figure 8. Expression of $N F \kappa B$ and IL8 genes in MCF7 cells following treatment with $5 \%$ larval aqueous and alcoholic extracts. Data are expressed as the mean \pm SEM. Samples were run in triplicate in three independent experiments, $n=5$. Groups with different letters are significantly different at $p<0.05$. ${ }^{*}$ indicates high significance with respect to the control $(p<0.01)$.

\section{Discussion}

There is growing interest in exploring the roles of the insects' bioactive components, especially those with antioxidant and anticancer properties. Previous studies have only investigated the anticancer effect of Vespa sp. venom and its bioactive peptides [36-38]. However, the effect of the venom is not selective and can damage normal cells [39,40]. Aside from the venom, insect developmental stages (larvae and pupae) exhibit antioxidant 
and anticancer potential, with less toxicity for normal cells. Dutta et al. [32] reported an antioxidant effect for $V$. affinis aqueous pupal extract. Moreover, the larval hemolymph of M. domestica had antioxidant and cytotoxic properties against MCF7, but no cytotoxicity on normal Vero cells [11]. To the best of our knowledge, this is the first study to report that $5 \%$ $V$. orientalis larval extracts had an anticancer effect on MCF7 cells, and that this effect could be mediated by, at least in part, the induction of apoptosis, activation of antioxidants, and inhibition of migration and inflammation.

Previous studies have demonstrated cytotoxic effects for $V$. orientalis venom and attributed this effect to a bioactive peptide called mastoparan, which causes membrane destabilization and subsequent cell lysis [48,49]. Mastoparan also activates G-protein, which subsequently initiates mitochondrial permeability and apoptosis [50]. However, little is known about the effect of $V$. orientalis larval extracts on cancer cells. In the present study, we studied this effect and reported a notable dose-dependent antiproliferative potential for $V$. orientalis larval extracts on MCF7 with better influence for the aqueous extract which showed lower $\mathrm{IC}_{50}(32.89 \pm 1.84 \mu \mathrm{g} / \mathrm{mL})$ than the alcoholic extract $(61.48 \pm 2.70 \mu \mathrm{g} / \mathrm{mL})$. This indicates a more potent anticancer effect for the aqueous larval extract. Unlike most insect venoms, these extracts are less toxic on normal cells such as Vero cells, indicating a high safety margin. This is in agreement with the safe consumption of many Vespa Sp. by some tribes in India [31]. However, in vivo investigations on animal models of cancer are required to validate their biosafety and choose the optimal doses.

Similar to $V$. orientalis venom and its ingredient mastoparan, the cytotoxic effect of larval extracts was mediated through induction of apoptosis as indicated by significant elevation of the three apoptotic genes Bax, caspase 3, and p53 and significant reduction of the anti-apoptotic $B c l 2$ gene with best apoptotic effect for the aqueous extract. Extracts used in the present study increased Bax, which induced the release of mitochondrial cytochrome c into the cytoplasm, further activating caspase 3 expression [51]. Thus, these extracts could inhibit MCF7 proliferation via the initiation of the intrinsic pathway of apoptosis. However, the extrinsic apoptotic pathway cannot be overlooked. Therefore, further investigations on caspase 8 and Fas-L are needed. These results are in agreement with previous reports on the potent anticancer effect of $M$. domestica larvae extract and hemolymph on CT26 and MCF7 cancer cells $[11,15]$ and C. albiceps larval extracts on a large variety of cancer cells including MCF7 [52].

Disrupting redox homeostasis is a central phenotype of several pathological states. Excessive oxidation harms different cellular components and is considered the hallmark for many diseases [53]. Reactive oxygen species (ROS) induce oxidative stress, which degrades proteins, lipids, and DNA [22,54,55]. The body prevents the over-release of free radicals and subsequently restricts oxidative stress through the activation of endogenous antioxidant enzymes (such as CAT, SOD, and GPx). Insects and their developmental stages (larvae and pupae) possess a powerful endogenous antioxidant system with a predominant effect for SOD [56,57]. Consistent with these findings, we also found that $V$. orientalis larval extracts possessed potent total antioxidant properties, as revealed by the DPPH assay. This effect was further proved on enzymatic and mRNA levels, and the results showed significant elevation in activities of antioxidant enzymes and expression of $\mathrm{NrF} 2$ and $\mathrm{HO}-1$ genes following treatment with larval extracts. We also demonstrated a significant reduction in intracellular ROS as an indicator for oxidative stress. Similarly, Dutta et al. [32] found potent antioxidant properties for $V$. affinis aqueous pupal extract with higher SOD, CAT, and GST activities in human plasma (in vitro) and lower intracellular ROS in monocytes. ElGarawani et al. [11] also reported an antioxidant effect for $M$. domestica larval hemolymph with higher levels of SOD, TAC, and GSH and lower lipoperoxidation marker MDA levels. Several other studies also showed antioxidant effects for insect larval extracts such as blowflies [58] and beetles [59]. Interestingly, the increased anticancer potential of the aqueous extract was associated with a higher antioxidant status, which could be due to the existence of the defense constituents in larvae. In support, antioxidants can hinder tumorigenesis and growth and trigger apoptosis in cancer cells $[11,23,60]$. In general, the 
inhibitory effect on excessive ROS release and induction of antioxidant enzymes imply an advantageous role of $V$. orientalis larval extracts against oxidative stress-dependent diseases and cancer.

One of the main features of a potent anticancer drug is its ability to not only kill cancer cells, but also to prevent metastasis. Most mortality from cancer may be related to metastasis and the subsequent multiorgan dysfunction. Interestingly, $V$. orientalis larval extracts inhibited MCF7 metastasis as noticed by the results of both wound healing assay (which showed a humbled migration) and qPCR (reduced expression of the migrationrelated gene $M M P 9$ and increased expression of the anti-migration gene TIMP1). Unlike apoptotic and antioxidant effects, which revealed a leading effect for aqueous extract, no significant difference was noticed between the two extracts with respect to their antimigration potential. Consistent with our results, cantharidin, a toxin extracted from beetles, also inhibited migration and invasion of human lung cancer cells through selective prevention of the expression of some MMP members [10].

The results obtained from qPCR revealed an anti-inflammatory effect for the larval extracts, as demonstrated by the downregulation of inflammation-related genes ( NFKB and IL8), but with a predominant effect for the alcoholic extract. Using a similar mechanism, V. orientalis venom also possessed an anti-inflammatory effect [61]. Additionally, aqueous extracts of the house cricket, grasshopper, and silk moth contain notable anti-inflammatory and antioxidant activities $[17,18]$. Cancer cells induce inflammation via their ability to release inflammatory cytokines into the tumor microenvironment $[62,63]$. Inflammation plays an important role in cancer initiation and metastasis. When MCF7 is exposed to cytokines for long period, they undergo epithelial-mesenchymal transition, thereby facilitating cancer cell migration and metastasis. Hence, inhibition of cytokines such as $N F \kappa B$ hinders breast cancer cell migration $[46,64]$. Taken together, we provide $V$. orientalis larval extracts as novel inhibitors for chemotaxis-based migration of MCF7 cells.

HPLC analysis revealed the presence of several flavonoids and phenolic compounds, with the highest concentrations being for resveratrol and naringenin in the aqueous extract and rosmarinic acid in the alcoholic extract. In addition to other unknown higher peaks which worth further investigation. Thus, we suggest that the anticancer and antioxidant properties of these extracts could be attributed, at least in part, to these flavonoids and phenolic compounds. High levels of resveratrol and naringenin in the aqueous extract could explain its predominant anticancer and antioxidant potential relative to the alcoholic extract. Resveratrol has an anticancer effect and can potentiate the chemotherapeutic potential, reduce multidrug resistance, and limit metastasis when used in combination with standard anticancer drugs (reviewed in [65]). Resveratrol also has potent antioxidant properties that are mediated via activation of Nrf2 and its downstream target $\mathrm{HO}-1$ in rat PC12 cells and normal human breast epithelial MCF10F cells [66]. It also induces the p53-dependent pathway in cancer cells [67]. Similarly, we also found that the resveratrolrich aqueous extract inhibited MCF7 proliferation, and this effect was accompanied by higher expression of $\mathrm{Nrf2}, \mathrm{HO}-1$, and $p 53$. Naringenin inhibits the viability of a large variety of cancer cells and diminishes their migration and invasion [68]. It has been considered to be a perfect surgical adjuvant treatment for breast cancer patients, as it can modulate patient immunity and subsequently preventing tumor metastases after surgery [69]. Its anti-metastasis effect was associated with AKT pathway inhibition and downregulation of MMP2 and MMP9 [68]. On the other hand, the abundant amount of rosmarinic acid in the alcoholic extract could justify its superior anti-inflammatory effect. Rosmarinic acid possesses anti-inflammatory and anticancer properties against several cancer cell lines [70]. It can also cease the migration of MDA-MB-231BO human breast cancer cells from the breast to the bone through inhibition of $N F \kappa B$ ligand (RANKL), osteoprotegerin, and IL8 expression [71]. Due to its potent anti-inflammatory effect, rosmarinic acid has been used in the treatment of inflammatory diseases such as arthritis, colitis, rhinitis, and acute pancreatitis through inhibition of cytokines including $N F \kappa B, I L 1 b$, and IL8 [72]. In 
parallel, we also reported that the rosmarinic acid enriched alcoholic extract minimized MCF7 growth, and this effect was associated with the downregulation of NFKB, and IL8.

This study provides new details regarding the anticancer effect of $V$. orientalis larval extracts against only one type of breast cancer cells (MCF7). However, it is worth confirming whether this effect also exists on other breast cancer cell lines to show that the observed effects are not only related to certain features in MCF7. Similarly, the effect of $V$. orientalis larval extract needs to be verified on animal models of breast cancer. Therefore, further in vitro and in vivo investigations are required to provide more mechanistic details in that regard.

\section{Conclusions}

Cancer cells maintain their viability via inhibition of apoptosis, initiation of inflammation, and migration. Stimulating apoptosis and targeting inflammation and migration can inhibit the proliferation of cancer cells and limit tumor progression. To the best of our knowledge, this is the first study to report that treatment with different $V$. orientalis larva extracts could inhibit MCF7 proliferation through induction of apoptosis, activation of antioxidant status, and inhibition of migration and inflammation. The aqueous extract showed the most potent anticancer effect, with a higher antioxidant effect but lower antiinflammatory properties than the alcoholic extract. Thus, V. orientalis larval extracts could be useful in the future as adjuvants for breast anticancer drugs and as antioxidant and anti-inflammatory agents in the treatment of oxidative stress and inflammation-related diseases. However, further in vivo preclinical studies are required to verify this effect in animal models and check whether these extracts could be clinically relevant and safe for patients.

Supplementary Materials: The following are available online. Figure S1: Expression of Bax, caspase3 (Cas3), p53, and Bcl2 genes in Vero cells following treatment with $5 \%$ aqueous and alcoholic larval extracts as detected by qPCR. Data were normalized to the housekeeping gene (GAPDH) and expressed as the mean fold change \pm SEM. Samples ran in triplicates in 3 independent experiments, $n=5$.

Author Contributions: Conceptualization, M.A.E.-M. and A.M.G.Z.; methodology, M.A.E.-M. and A.M.G.Z.; software, O.B. and Y.M.H.; validation, M.I.S., O.A.-A., A.A.A.O. and S.K.N.E.; formal analysis, M.A.E.-M. and A.M.G.Z.; investigation, M.A.E.-M., A.M.G.Z., O.B. and Y.M.H.; resources, M.I.S., O.A.-A., A.A.A.O. and S.K.N.E.; data curation, M.A.E.-M. and A.M.G.Z.; writing-original draft preparation, M.A.E.-M. and A.M.G.Z.; writing-review and editing, M.A.E.-M. and A.M.G.Z.; visualization, O.B. and Y.M.H.; supervision, M.I.S., O.A.-A., A.A.A.O. and S.K.N.E.; project administration, O.A.-A., A.A.A.O. and S.K.N.E.; funding acquisition, O.B., Y.M.H., M.I.S., O.A.-A., A.A.A.O. and S.K.N.E. All authors have read and agreed to the published version of the manuscript.

Funding: This research received no external funding.

Institutional Review Board Statement: Not applicable.

Informed Consent Statement: Not applicable.

Data Availability Statement: Not applicable.

Conflicts of Interest: The authors declare no conflict of interest.

Sample Availability: Samples of the compounds are not available from the authors.

\section{References}

1. Deng, Y.; Sriwiriyajan, S.; Tedasen, A.; Hiransai, P.; Graidist, P. Anti-cancer effects of piper nigrum via inducing multiple molecular signaling in vivo and in vitro. J. Ethnopharmacol. 2016, 188, 87-95. [CrossRef] [PubMed]

2. Abu Gazia, M.; El-Magd, M.A. Ameliorative effect of cardamom aqueous extract on doxorubicin-induced cardiotoxicity in rats. Cellstissuesorgans 2018, 206, 62-72. [CrossRef] [PubMed]

3. Kozłowski, J.; Kozłowska, A.; Kocki, J. Breast cancer metastasis-Insight into selected molecular mechanisms of the phenomenon. Postepy Hig. I Med. Dosw. 2015, 69, 447-451. [CrossRef] [PubMed]

4. Magdy, A.; Sadaka, E.; Hanafy, N.; El-Magd, M.A.; Allahloubi, N.; El Kemary, M. Green tea ameliorates the side effects of the silver nanoparticles treatment of ehrlich ascites tumor in mice. Mol. Cell. Toxicol. 2020, 16, 271-282. [CrossRef] 
5. $\quad$ El-Magd, M.A.; Mohamed, Y.; El-Shetry, E.S.; Elsayed, S.A.; Abo Gazia, M.; Abdel-Aleem, G.A.; Shafik, N.M.; Abdo, W.S.; El-Desouki, N.I.; Basyony, M.A. Melatonin maximizes the therapeutic potential of non-preconditioned mscs in a den-induced rat model of hcc. Biomed. Pharmacother. 2019, 114, 108732. [CrossRef] [PubMed]

6. Awad, M.G.; Ali, R.A.; Abd El-Monem, D.D.; El-Magd, M.A. Graviola leaves extract enhances the anticancer effect of cisplatin on various cancer cell lines. Mol. Cell. Toxicol. 2020, 16, 385-399. [CrossRef]

7. Attia, A.M.; Khodair, A.I.; Gendy, E.A.; El-Magd, M.A.; Elshaier, Y.A. New 2-oxopyridine/2-thiopyridine derivatives tethered to a benzotriazole with cytotoxicity on mcf7 cell lines and with antiviral activities. Lett. Drug Des. Discov. 2020, 17, 124-137. [CrossRef]

8. Pettit, G.R.; Meng, Y.; Herald, D.L.; Knight, J.C.; Day, J.F. Antineoplastic agents. 553. The texas grasshopper Brachystola magna. J. Nat. Prod. 2005, 68, 1256-1258. [CrossRef]

9. Lee, J.-E.; Jo, D.-E.; Lee, A.-J.; Park, H.-K.; Youn, K.; Yun, E.-Y.; Hwang, J.-S.; Jun, M.; Kang, B.H. Hepatoprotective and anticancer activities of allomyrina dichotoma larvae. J. Life Sci. 2015, 25, 307-316. [CrossRef]

10. Kim, Y.M.; Ku, M.J.; Son, Y.-J.; Yun, J.-M.; Kim, S.H.; Lee, S.Y. Anti-metastatic effect of cantharidin in a549 human lung cancer cells. Arch. Pharm. Res. 2013, 36, 479-484. [CrossRef]

11. El-Garawani, I.; El-Seedi, H.; Khalifa, S.; El Azab, I.H.; Abouhendia, M.; Mahmoud, S. Enhanced antioxidant and cytotoxic potentials of lipopolysaccharides-injected musca domestica larvae. Pharmaceutics 2020, 12, 1111. [CrossRef]

12. Yan, Y.-M.; Li, L.-J.; Qin, X.-C.; Lu, Q.; Tu, Z.-C.; Cheng, Y.-X. Compounds from the insect blaps japanensis with cox-1 and cox-2 inhibitory activities. Bioorg. Med. Chem. Lett. 2015, 25, 2469-2472. [CrossRef] [PubMed]

13. An, C.; Li, D.; Du, R. Analysis of antibacterial-relative proteins and peptides in housefly larvae. Wei Sheng Yan Jiu J. Hyg. Res. 2004, 33, 86-88.

14. Sun, H.-X.; Chen, L.-Q.; Zhang, J.; Chen, F.-Y. Anti-tumor and immunomodulatory activity of peptide fraction from the larvae of musca domestica. J. Ethnopharmacol. 2014, 153, 831-839. [CrossRef]

15. Hou, L.; Shi, Y.; Zhai, P.; Le, G. Antibacterial activity and in vitro anti-tumor activity of the extract of the larvae of the housefly (Musca domestica). J Ethnopharmacol. 2007, 111, 227-231. [CrossRef] [PubMed]

16. Guo, G.; Tao, R.; Li, Y.; Ma, H.; Xiu, J.; Fu, P.; Wu, J. Identification and characterization of a novel antimicrobial protein from the housefly Musca domestica. Biochem. Biophys. Res. Commun. 2017, 490, 746-752. [CrossRef] [PubMed]

17. Di Mattia, C.; Battista, N.; Sacchetti, G.; Serafini, M. Antioxidant activities in vitro of water and liposoluble extracts obtained by different species of edible insects and invertebrates. Front. Nutr. 2019, 6, 106. [CrossRef] [PubMed]

18. Zielińska, E.; Karaś, M.; Jakubczyk, A. Antioxidant activity of predigested protein obtained from a range of farmed edible insects. Int. J. Food Sci. Technol. 2017, 52, 306-312. [CrossRef]

19. Van Huis, A.; Van Itterbeeck, J.; Klunder, H.; Mertens, E.; Halloran, A.; Muir, G.; Vantomme, P. Edible Insects: Future Prospects for Food and Feed Security; Food and Agriculture Organization of the United Nations: Rome, Italy, 2013.

20. Abu Khudir, R.; El-Magd, M.A.; Salama, A.F.; Tousson, E.M.; El-Dsoki, S.M. Curcumin attenuated oxidative stress and inflammation on hepatitis induced by fluvastatin in female albino rats. Alex. J. Vet. Sci. 2019, 62, 102-115. [CrossRef]

21. El-Demerdash, F.M.; El-Magd, M.A.; El-Sayed, R.A. Panax ginseng modulates oxidative stress, DNA damage, apoptosis, and inflammations induced by silicon dioxide nanoparticles in rats. Environ. Toxicol. 2021. [CrossRef]

22. Khamis, A.A.A.; Ali, E.M.M.; El-Moneim, M.A.A.; Abd-Alhaseeb, M.M.; El-Magd, M.A.; Salim, E.I. Hesperidin, piperine and bee venom synergistically potentiate the anticancer effect of tamoxifen against breast cancer cells. Biomed. Pharmacother. 2018, 105, 1335-1343. [CrossRef] [PubMed]

23. O'Brien, P.J. Antioxidants and cancer: Molecular mechanisms. Free Radic. Diagn. Med. 1994, 366, $215-239$.

24. Haddad, N.J.; Fuchs, S.; Haddaden, J.; Kopelke, J.-P. Record of Sphecophaga vesparum Curtis, a natural enemy of Vespa orientalis in northern Jordan. Zool. Middle East 2005, 35, 114-116. [CrossRef]

25. Bagriacik, N. Determination of some structural features of the nest paper of Vespa orientalis linneaus, 1771 and Vespa crabro linneaus, 1758 (hymenoptera: Vespinae) in Turkey. Arch. Biol. Sci. 2011, 63, 449-455. [CrossRef]

26. Dehghani, R.; Kassiri, H.; Mazaheri-Tehrani, A.; Hesam, M.; Valazadi, N.; Mohammadzadeh, M. A study on habitats and behavioral characteristics of hornet wasp (hymenoptera: Vespidae: Vespa orientalis), an important medical-health pest. Biomed. Res. 2019, 30. [CrossRef]

27. Ebrahimi, E.; Carpenter, J.M. Distribution pattern of the hornets vespa orientalis and v. Crabro in iran: (hymenoptera: Vespidae). Zool. Middle East 2012, 56, 63-66. [CrossRef]

28. Ishak, H.D.; Miller, J.L.; Sen, R.; Dowd, S.E.; Meyer, E.; Mueller, U.G.J.S.R. Microbiomes of ant castes implicate new microbial roles in the fungus-growing ant trachymyrmex septentrionalis. Sci. Rep. 2011, 1, 204. [CrossRef]

29. Papachristoforou, A.; Sueur, J.; Rortais, A.; Angelopoulos, S.; Thrasyvoulou, A.; Arnold, G.J.A. High frequency sounds produced by cyprian honeybees apis mellifera cypria when confronting their predator, the oriental hornet vespa orientalis. Apidologie 2008, 39, 468-474. [CrossRef]

30. Ken, T.; Hepburn, H.R.; Radloff, S.E.; Yusheng, Y.; Yiqiu, L.; Danyin, Z.; Neumann, P. Heat-balling wasps by honeybees. Naturwissenschaften 2005, 92, 492-495. [CrossRef]

31. Narzari, S.; Sarmah, J. Proximate composition of wild edible insects consumed by the bodo tribe of assam, india. Int. J. Bioassays 2015, 4, 4050-4054.

32. Dutta, P.; Dey, T.; Manna, P.; Kalita, J. Antioxidant potential of Vespa affinis L., a traditional edible insect species of north east India. PLoS ONE 2016, 11, e0156107. [CrossRef] 
33. Jalaei, J.; Fazeli, M.; Rajaian, H.; Shekarforoush, S.S. In vitro antibacterial effect of wasp (Vespa orientalis) venom. J. Venom. Anim. Toxins Incl. Trop. Dis. 2014, 20, 22. [CrossRef]

34. Jalaei, J.; Layeghi-Ghalehsoukhteh, S.; Hosseini, A.; Fazeli, M. Antibacterial effects of gold nanoparticles functionalized with the extracted peptide from vespa orientalis wasp venom. J. Pept. Sci. 2018, 24, e3124. [CrossRef]

35. Lee, S.H.; Baek, J.H.; Yoon, K.A. Differential properties of venom peptides and proteins in solitary vs. Social hunting wasps. Toxins 2016, 8, 32. [CrossRef] [PubMed]

36. Mukund, H.; Manjunath, P.M. Comparative enzyme activity of Vespa orientalis venom and its photooxidized venom products. J. Biochem. Biophys. 2017, 1, 104.

37. Leite, N.B.; Aufderhorst-Roberts, A.; Palma, M.S.; Connell, S.D.; Neto, J.R.; Beales, P.A. Pe and ps lipids synergistically enhance membrane poration by a peptide with anticancer properties. Biophys. J. 2015, 109, 936-947. [CrossRef] [PubMed]

38. Moreno, M.; Zurita, E.; Giralt, E. Delivering wasp venom for cancer therapy. J. Control. Release 2014, 182, 13-21. [CrossRef] [PubMed]

39. Saidemberg, D.M.; da Silva-Filho, L.C.; Tognoli, L.M.C.; Tormena, C.F.; Palma, M.S. Polybioside, a neuroactive compound from the venom of the social wasp Polybia paulista. J. Nat. Prod. 2010, 73, 527-531. [CrossRef] [PubMed]

40. Barenholz-Paniry, V.; Ishay, J.S.; Pick, I.A.; Hammel, I. Mast cell activation by hornet (Vespa orientalis) venom. Int. Arch. Allergy Appl. Immunol. 1990, 93, 178-183. [CrossRef]

41. Hasaballah, A.I.; Shehata, A.Z.; Shehab, A.M. Antioxidant and anticancer activities of some maggots methanol extracts. Egypt. Acad. J. Biol. Sci. A Entomol. 2019, 12, 111-119. [CrossRef]

42. Eldin, S.; Ziena, H.; Khair, S.; Rozan, M. Canola seed meal as a potential source of natural antioxidant. Alex. Sci. Exch. J. 2018, 39, 615-619.

43. Azaam, M.M.; Kenawy, E.-R.; El-din, A.S.B.; Khamis, A.A.; El-Magd, M.A. Antioxidant and anticancer activities of $\alpha-$ aminophosphonates containing thiadiazole moiety. J. Saudi Chem. Soc. 2018, 22, 34-41. [CrossRef]

44. Habib, E.S.; El-Bsoumy, E.; Ibrahim, A.K.; Helal, M.A.; El-Magd, M.A.; Ahmed, S.A. Anti-inflammatory effect of methoxyflavonoids from Chiliadenus montanus (Jasonia montana) growing in Egypt. Nat. Prod. Res. 2020, 1802272. [CrossRef]

45. El-Magd, M.A.; Khalifa, S.F.; Alzahrani, F.A.A.; Badawy, A.A.; El-Shetry, E.S.; Dawood, L.M.; Alruwaili, M.M.; Alrawaili, H.A.; Risha, E.F.; El-Taweel, F.M.; et al. Incensole acetate prevents beta-amyloid-induced neurotoxicity in human olfactory bulb neural stem cells. Biomed. Pharmacother. 2018, 105, 813-823. [CrossRef]

46. Badawy, A.A.; El-Magd, M.A.; AlSadrah, S.A. Therapeutic effect of camel milk and its exosomes on mcf7 cells in vitro and in vivo. Integr. Cancer Ther. 2018, 7, 1235-1246. [CrossRef]

47. Livak, K.J.; Schmittgen, T.D. Analysis of relative gene expression data using real-time quantitative pcr and the $2^{-\Delta \Delta C t}$ method. Methods 2001, 25, 402-408. [CrossRef]

48. Higashijima, T.; Uzu, S.; Nakajima, T.; Ross, E.M. Mastoparan, a peptide toxin from wasp venom, mimics receptors by activating gtp-binding regulatory proteins (g proteins). J. Biol. Chem. 1988, 263, 6491-6494. [CrossRef]

49. Danilenko, M.; Worland, P.; Carlson, B.; Sausville, E.A.; Sharoni, Y. Selective effects of mastoparan analogs: Separation of g-protein-directed and membrane-perturbing activities. Biochem. Biophys. Res. Commun. 1993, 196, 1296-1302. [CrossRef]

50. Leite, N.B.; da Costa, L.C.; Dos Santos Alvares, D.; Dos Santos Cabrera, M.P.; de Souza, B.M.; Palma, M.S.; Ruggiero Neto, J. The effect of acidic residues and amphipathicity on the lytic activities of mastoparan peptides studied by fluorescence and cd spectroscopy. Amino Acids 2011, 40, 91-100. [CrossRef]

51. Moghadamtousi, S.Z.; Kadir, H.A.; Paydar, M.; Rouhollahi, E.; Karimian, H. Annona muricata leaves induced apoptosis in a549 cells through mitochondrial-mediated pathway and involvement of nf-kappab. BMC Complement. Altern. Med. 2014, 14, 299. [CrossRef] [PubMed]

52. Shehata, A.Z.; Mehany, A.B.; El-Sheikh, T.M. Excretion/secretion of lucilia sericata and chrysomya albiceps (diptera: Calliphoridae) maggots as potential anticancer agent and kinases inhibitor. N. Y. Sci. J. 2016, 9, 95-101.

53. Gaschler, M.M.; Stockwell, B.R. Lipid peroxidation in cell death. Biochem. Biophys. Res. Commun. 2017, 482, 419-425. [CrossRef] [PubMed]

54. Elkeiy, M.; Khamis, A.; El-Gamal, M.; Abo Gazia, M.; Zalat, Z.; El-Magd, M. Chitosan nanoparticles from artemia salina inhibit progression of hepatocellular carcinoma in vitro and in vivo. Environ. Sci. Pollut. Res. Int. 2018, 27, 19016-19028. [CrossRef]

55. Alzahrani, F.A.; El-Magd, M.A.; Abdelfattah-Hassan, A.; Saleh, A.A.; Saadeldin, I.M.; El-Shetry, E.S.; Badawy, A.A.; Alkarim, S. Potential effect of exosomes derived from cancer stem cells and mscs on progression of den-induced hcc in rats. Stem Cells Int. 2018, 2018, 8058979. [CrossRef]

56. Pritsos, C.A.; Ahmad, S.; Elliott, A.J.; Pardini, R.S. Antioxidant enzyme level response to prooxidant allelochemicals in larvae of the southern armyworm moth, spodoptera eridania. Free Radic. Res. Commun. 1990, 9, 127-133. [CrossRef]

57. Wang, Y.; Oberley, L.W.; Murhammer, D.W. Antioxidant defense systems of two lipidopteran insect cell lines. Free Radic. Biol. Med. 2001, 30, 1254-1262. [CrossRef]

58. Song, C.; Yu, H.; Zhang, M.; Yang, Y.; Zhang, G. Physicochemical properties and antioxidant activity of chitosan from the blowfly Chrysomya megacephala larvae. Int. J. Biol. Macromol. 2013, 60, 347-354. [CrossRef]

59. Suh, H.-J.; Kim, S.-R.; Lee, K.-S.; Park, S.; Kang, S.C. Antioxidant activity of various solvent extracts from Allomyrina dichotoma (arthropoda: Insecta) larvae. J. Photochem. Photobiol. B Biol. 2010, 99, 67-73. [CrossRef] [PubMed] 
60. Tsai, J.-C.; Jain, M.; Hsieh, C.-M.; Lee, W.-S.; Yoshizumi, M.; Patterson, C.; Perrella, M.A.; Cooke, C.; Wang, H.; Haber, E. Induction of apoptosis by pyrrolidinedithiocarbamate and n-acetylcysteine in vascular smooth muscle cells. J. Biol. Chem. 1996, 271, 3667-3670. [CrossRef]

61. Mahdi, R.K.; Al-Hassnawi, A.T.S.; AL-Rubaei, H.M. Biochemical Investigation Effect of Vespa Orientalis Venom Therapy: Rat Rheumatoid Arthritis Model. In AIP Conference Proceedings; AIP Publishing LLC: Melville, NY, USA, $2019 ;$ p. 040004.

62. Bonavita, E.; Galdiero, M.R.; Jaillon, S.; Mantovani, A. Phagocytes as corrupted policemen in cancer-related inflammation. Adv. Cancer Res. 2015, 128, 141-171. [PubMed]

63. Elgazar, A.A.; Selim, N.M.; Abdel-Hamid, N.M.; El-Magd, M.A.; El Hefnawy, H.M. Isolates from alpinia officinarum hance attenuate lps induced inflammation in hepg2: Evidence from in silico and in vitro studies. Phytother. Res. 2018, 32, 1273-1288. [CrossRef]

64. Han, J.; Bae, S.Y.; Oh, S.J.; Lee, J.; Lee, J.H.; Lee, H.C.; Lee, S.K.; Kil, W.H.; Kim, S.W.; Nam, S.J.; et al. Zerumbone suppresses il-1beta-induced cell migration and invasion by inhibiting il-8 and mmp-3 expression in human triple-negative breast cancer cells. Phytother. Res. 2014, 28, 1654-1660. [CrossRef]

65. Ko, J.-H.; Sethi, G.; Um, J.-Y.; Shanmugam, M.K.; Arfuso, F.; Kumar, A.P.; Bishayee, A.; Ahn, K.S. The role of resveratrol in cancer therapy. Int. J. Mol. Sci. 2017, 18, 2589. [CrossRef]

66. Lu, F.; Zahid, M.; Wang, C.; Saeed, M.; Cavalieri, E.L.; Rogan, E.G. Resveratrol prevents estrogen-DNA adduct formation and neoplastic transformation in mcf-10f cells. Cancer Prev. Res. 2008, 1, 135-145. [CrossRef]

67. Hsieh, T.C.; Wong, C.; John Bennett, D.; Wu, J.M. Regulation of p53 and cell proliferation by resveratrol and its derivatives in breast cancer cells: An in silico and biochemical approach targeting integrin $\alpha \mathrm{v} \beta 3$. Int. J. Cancer 2011, 129, 2732-2743. [CrossRef]

68. Chang, H.L.; Chang, Y.M.; Lai, S.C.; Chen, K.M.; Wang, K.C.; Chiu, T.T.; Chang, F.H.; Hsu, L.S. Naringenin inhibits migration of lung cancer cells via the inhibition of matrix metalloproteinases-2 and -9. Exp. Ther. Med. 2017, 13, 739-744. [CrossRef] [PubMed]

69. Qin, L.; Jin, L.; Lu, L.; Lu, X.; Zhang, C.; Zhang, F.; Liang, W. Naringenin reduces lung metastasis in a breast cancer resection model. Protein Cell 2011, 2, 507-516. [CrossRef] [PubMed]

70. Han, Y.H.; Kee, J.Y.; Hong, S.H. Rosmarinic acid activates ampk to inhibit metastasis of colorectal cancer. Front. Pharm. 2018, 9, 68. [CrossRef] [PubMed]

71. Xu, Y.; Jiang, Z.; Ji, G.; Liu, J. Inhibition of bone metastasis from breast carcinoma by rosmarinic acid. Planta Med. 2010, 76, 956-962. [CrossRef]

72. Luo, C.; Zou, L.; Sun, H.; Peng, J.; Gao, C.; Bao, L.; Ji, R.; Jin, Y.; Sun, S. A review of the anti-inflammatory effects of rosmarinic acid on inflammatory diseases. Front. Pharm. 2020, 11, 153. [CrossRef] [PubMed] 